\title{
Rationale for Combination Angiotensin Receptor Blocker and Angiotensin-Converting Enzyme Inhibitor Treatment and End-Organ Protection in Patients with Chronic Kidney Disease
}

\author{
Robert Toto $^{a}$ Biff F. Palmer ${ }^{b}$ \\ ${ }^{\mathrm{a} D}$ Director, Patient-Oriented Research - Nephrology, and ${ }^{\mathrm{b}}$ Director, Nephrology Fellowship Program, \\ University of Southwestern Medical Center at Dallas, Dallas, Tex., USA
}

\begin{abstract}
Key Words
Angiotensin-converting enzyme inhibitor $\cdot$ Angiotensin receptor blocker $\cdot$ Chronic kidney disease $\cdot$ Combination therapy $\cdot$ Renin-angiotensin-aldosterone system
\end{abstract}

\begin{abstract}
Chronic kidney disease (CKD) is a major public health problem that has received increasing attention because of the high rate of associated cardiovascular morbidity and mortality. Mounting evidence indicates that angiotensin-converting enzyme (ACE) inhibitors and angiotensin receptor blockers (ARBs), drugs that inhibit the renin-angiotensinaldosterone system (RAAS) safely slow down progression of CKD. There is also growing evidence supporting combination treatment of nephropathies with an ACE inhibitor plus an ARB to more completely block the RAAS and provide greater renoprotection than either an ACE inhibitor-based or ARB-based regimen. The National Kidney Foundation suggests that ACE inhibitors and ARBs may be used in combination to reduce proteinuria in patients with kidney disease; however, larger outcomes trials are needed.
\end{abstract}

Copyright $\odot 2007$ S. Karger AG, Basel

\section{Introduction}

Chronic kidney disease (CKD) is defined by the National Kidney Foundation as kidney damage or an estimated glomerular filtration rate (GFR) of $<60 \mathrm{ml} /$ $\min / 1.73 \mathrm{~m}^{2}$ of at least 3 months' duration [1]. It may manifest as abnormalities in urinalysis, imaging studies, or blood measurements of kidney function. Stages of CKD are based on estimated GFR $\left(\mathrm{ml} / \mathrm{min} / 1.73 \mathrm{~m}^{2}\right)$ as follows: (1) normal or elevated (>90), with kidney damage; (2) mildly decreased (60-89), with kidney damage; (3) moderately decreased (30-59); (4) severely decreased $(15-29)$, and (5) kidney failure $(<15)$. CKD is often progressive and can lead to loss of kidney function, kidney failure, and cardiovascular disease; in addition, decreased GFR is associated with hypertension, anemia, malnutrition, bone disease, and neuropathy. The most common cause of CKD and kidney failure is type 2 diabetes, which accounts for about $40 \%$ of new cases of end-stage renal disease (ESRD) [2]. Other common causes are other glomerular diseases, vascular diseases, tubulointerstitial diseases, and cystic diseases [3]. Modifiable risk factors for the development and progression of CKD include hypertension, diabetes and poor diabetes control, hyperlipidemia, obesity, smoking, proteinuria, and possibly use of some analgesics (paracetamol and nonsteroidal anti-inflammatory agents) combined with caffeine [4].

Robert Toto, MD

Director of Patient-Oriented Research - Nephrology

University of Southwestern Medical Center at Dallas

5323 Harry Hines Boulevard, Dallas, TX 75225-8856 (USA)

Tel. +1 214274 7577, Fax +1 214692 8738, E-Mail robert.toto@utsouthwestern.edu
Fax +41 613061234

E-Mail karger@karger.ch Accessible online at:

www.karger.com

www.karger.com/ajn

\section{0-8095/08/0283-0372\$24.50/0}


Fig. 1. The RAAS hormonal cascade. RAAS = Renin-angiotensin-aldosterone system; TPA $=$ tissue plasminogen activator; CAGE = chymostatin-sensitive angiotensin II-generating enzyme; $\mathrm{ACE}=$ angiotensin-converting enzyme; PAI = plasminogen-activator inhibitor. Adapted with permission from Brewster et al. [7].

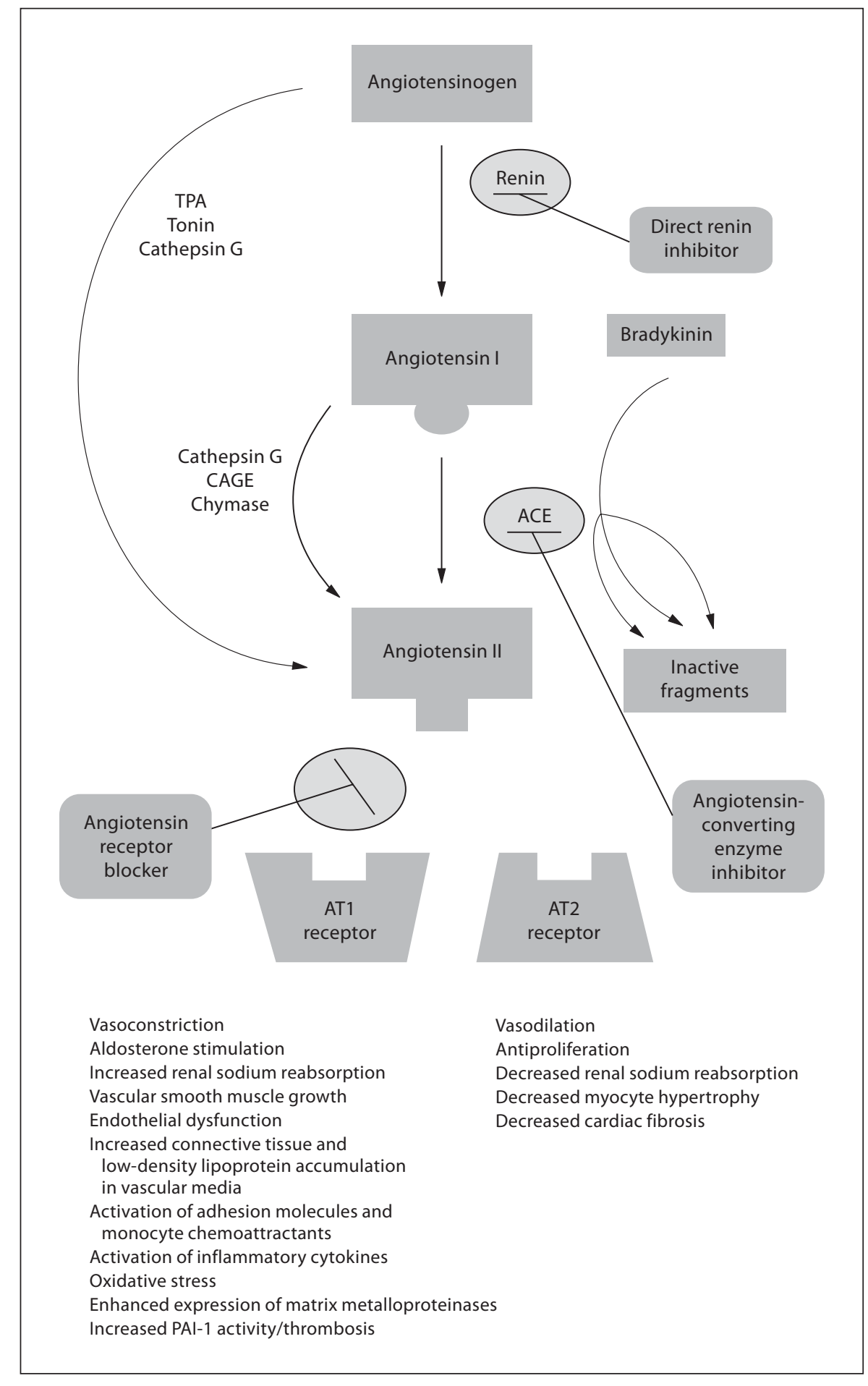

CKD is a major public health problem in the USA. According to an analysis of the nationally representative Third National Health and Nutrition and Examination Survey (NHANES III, 1988-1994), approximately $11 \%$ of adults in the USA have some degree of CKD: $6.3 \%$ stage 1 or $2,4.3 \%$ stage $3,0.2 \%$ stage 4 , and $0.2 \%$ stage 5 [1]. The prevalence of $\mathrm{CKD}$, including that requiring dialysis, is rising sharply; according to studies of general Medicare 
patients, the rate of chronic kidney disease has more than doubled in the past decade [2]. Moreover, data from NHANES III and NHANES II (1976-1980) show the increase in incident ESRD has outpaced the increase in prevalent chronic kidney disease [5]. The relative risk for progression to ESRD among people with CKD increased about $70 \%$ between the study periods of NHANES II and III; it is estimated that in 2010 , there will be 650,000 cases [6].

\section{The Renin-Angiotensin-Aldosterone System and Its Role in the Pathophysiology of CKD}

The renin-angiotensin-aldosterone system (RAAS) is a cascade of hormones, triggered by release of renin from the kidney (fig. 1) [7]. Renin is a proteolytic enzyme stored in the juxtaglomerular cells around the afferent glomerular arterioles and normally released in response to stimuli such as reduced kidney flow or increased sympathetic tone [3]. Renin acts locally and in circulation to cleave angiotensinogen, a substrate that is constitutively secreted by the liver, into the inactive peptide angiotensin I [7]. Angiotensin I, in turn, is converted into angiotensin II by the enzyme angiotensin-converting enzyme (ACE), which is generated by endothelial cells in the lung and vasculature and by cell membranes in the kidneys, heart, and brain. Angiotensin II may also be generated by alternative pathways, which may be upregulated in the vascular endothelium by mechanical stretch, turbulence, and physical injury; in addition, angiotensin II may be generated from angiotensinogen by tissue plasminogen activator, cathepsin G, and tonin, or from angiotensin I by chymostatin-sensitive angiotensin II-generating enzyme, chymase, and cathepsin G.

Angiotensin II plays an important role in the regulation of fluid homeostasis and vascular resistance through specific receptors distributed throughout the body. The $\mathrm{AT}_{1}$ receptor is the most abundantly expressed receptor and mediates the majority of the known effects of angiotensin II. In the glomerular arterioles, $\mathrm{AT}_{1}$ activation reduces renal blood flow, increases GFR, and enhances proximal tubular sodium and fluid reabsorption. The $\mathrm{AT}_{1}$ receptor contributes to blood pressure regulation through direct effects on the vasculature and by increasing sympathetic outflow. In the adrenal gland, $\mathrm{AT}_{1}$ activation stimulates aldosterone synthesis; aldosterone binding and activation of mineralocorticoid receptors stimulate sodium reabsorption in the distal nephron. Angiotensin II can also stimulate the $\mathrm{AT}_{2}$ receptor. This receptor is primarily expressed during fetal development, where it plays a major role in organogenesis. In the normal adult, the $\mathrm{AT}_{2}$ receptor has a much more limited distribution and is upregulated under conditions of tissue ischemia or injury. The function of the $\mathrm{AT}_{2}$ receptor is still poorly understood, but it may play a role in counterbalancing the effects of $\mathrm{AT}_{1}$ receptor stimulation.

There is substantial evidence that upregulation of the RAAS plays a key role in the development and progression of CKD. Angiotensin II is involved in the development of glomerular hypertension, which causes hemodynamic changes associated with an increase in glomerular capillary pressure, progressive proteinuria, and glomerulosclerosis. The development of proteinuria by itself may further exacerbate renal injury. Exposure of renal tubular cells to protein incites the release of proinflammatory cytokines that can cause an influx of cells, resulting in further injury. $\mathrm{AT}_{1}$ activation also has mitogenic effects; it stimulates production of cytokines and growth factors, such as transforming growth factor- $\beta$, which contributes to renal injury by promoting the development of glomerulosclerosis and tubulointerstitial fibrosis. Free oxygen radicals formed as a result of increased levels of angiotensin II accelerate consumption of nitric oxide. Such changes can lead to endothelial dysfunction and hypertrophy of the renal vasculature.

\section{RAAS Blockade}

Clinical studies demonstrate that drugs that block the RAAS, including ACE inhibitors and angiotensin receptor blockers (ARBs), slow the progression of both diabetic and nondiabetic CKD. ACE inhibitors and ARBs are therefore recommended by the American Diabetes Association to treat albuminuria [8], by the Seventh Report of the Joint National Committee on Prevention, Detection, Evaluation, and Treatment of High Blood Pressure to treat CKD in patients with hypertension [9], and by the National Kidney Foundation to treat diabetic and nondiabetic kidney disease with proteinuria in patients with or without hypertension [3].

The key role of the RAAS in CKD is supported by the association between CKD and polymorphisms of genes encoding components of the RAAS [10-12] and by the well-established efficacy of ACE inhibitors and ARBs in renal outcomes. In a meta-analysis of 13 randomized placebo-controlled trials in patients with renal disease, treatment with ACE inhibitors or ARBs was more effective in reducing risk of ESRD, serum creatinine levels, 
and albuminuria compared with other antihypertensive drugs (table 1) [13]. Whereas ACE inhibitors and ARBs lower blood pressure, and there is an association between blood pressure reduction and reduction in the incidence of ESRD and albuminuria [13], several studies demonstrate that both classes of agents have specific renoprotective effects beyond those resulting from lowering blood pressure [14-20]. Significant long-term benefits of ACE inhibitors and ARBs have been observed, including reduced risk of ESRD, reduced proteinuria, and increased serum albumin levels, beyond the effects of reducing blood pressure.

\section{Combination Treatment with an ACE Inhibitor Plus an ARB}

Studies suggest that more complete blockade of the RAAS and greater renoprotection may be achieved by coadministration of an ACE inhibitor and an ARB-based regimen compared with ACE inhibitor-based regimens. One possibility is that ACE inhibitor-based regimens may not completely block the formation of angiotensin II, because of alternative pathways [7]. For example, with chronic ACE inhibition, there is evidence of a partial escape of ACE, reflected by shorter duration of angiotensin II suppression [21]. The efficacy of ARBs may be compromised with chronic use by a compensatory increase in levels of angiotensin II, which may compete with and displace ARBs from $\mathrm{AT}_{1}$ receptors [22]. Furthermore, the efficacy of ACE inhibitors and ARBs may be limited by their tissue penetration and pharmacokinetic profiles $[22,23]$. Ideal properties of drugs for RAAS inhibition and renoprotection include a high degree of bioavailability, large volume of tissue distribution, favorable protein binding, long plasma half-life, nonrenal mode of elimination, and, for ARBs, insurmountable (noncompetitive) $\mathrm{AT}_{1}$ antagonism [23]. The use of combination therapy may overcome the limits of therapy with either an ACE inhibitor- or an ARB-based regimen to provide greater RAAS inhibition and therefore renoprotection.

The results of short-term trials support the use of combination therapy with an ACE inhibitor and an ARB. In 8- to 16-week trials in patients with diabetic nephropathy, combination-based therapy, compared with ACE inhibitor-based therapy, was well tolerated and had greater efficacy in reducing plasma aldosterone level, proteinuria, urinary transforming growth factor- $\beta$, albuminuria, and GFR; this has been demonstrated with various drug combinations, including lisinopril plus candesartan [24];

ARB/ACE Inhibitor for End-Organ

Protection in CKD
Table 1. Renal outcomes with ACE inhibitors or ARBs versus other non-RAAS antihypertensive drugs in a meta-analysis of 13 randomized trials assessing antihypertensive drugs and progression of renal disease

\begin{tabular}{ll}
\hline Outcome & $\begin{array}{l}\text { Comparison between ACE } \\
\text { inhibitors or ARBs and } \\
\text { non-RAAS antihypertensives }\end{array}$ \\
\hline End-stage renal disease & $\begin{array}{l}\text { Relative risk, 0.87 } \\
\text { (95\% CI, 0.75 to 0.99) }\end{array}$ \\
\hline $\begin{array}{l}\text { Doubling of serum creatinine } \\
\text { levels }\end{array}$ & $\begin{array}{l}\text { Relative risk, 0.71 } \\
(95 \% \text { CI, } 0.49 \text { to } 1.04)\end{array}$ \\
\hline $\begin{array}{l}\text { Change in serum creatinine } \\
\text { levels }\end{array}$ & $\begin{array}{l}\text { Mean difference, }-7.07 \mu \text { mol/1 } \\
(95 \% \text { CI, }-13.26 \text { to }-0.88)\end{array}$ \\
\hline Change in albuminuria & $\begin{array}{l}\text { Mean difference, }-15.73 \\
(95 \% \text { CI, }-24.72 \text { to }-6.74)\end{array}$ \\
\hline $\begin{array}{l}\text { Change in glomerular } \\
\text { filtration rate }\end{array}$ & $\begin{array}{l}\text { Mean difference, } 0.28 \\
(95 \% \text { CI, }-0.76 \text { to } 1.32)\end{array}$ \\
\hline
\end{tabular}

$\mathrm{ACE}=$ Angiotensin-converting enzyme; $\mathrm{ARB}=$ angiotensin receptor blocker; RAAS = renin-angiotensin aldosterone system; $\mathrm{CI}=$ confidence interval.

benazepril plus valsartan [25]; captopril, enalapril, or lisinopril plus irbesartan [26] or candesartan [27, 28]; enalapril plus irbesartan [29]; perindopril plus irbesartan [30], and ramipril plus candesartan [31]. Similar results were found in trials including patients with nondiabetic nephropathies [32], including immunoglobulin A (IgA) nephropathy [33,34] glomerulonephritis [35, 36], and primary glomerulonephritis and nonnephrotic proteinuria [37], and in trials in patients with various types of nephropathy, including diabetic nephropathy or glomerulonephritis [38], reflux nephropathy, IgA glomerulonephritis, focal sclerosis, diabetic nephropathy, membranous glomerulonephritis, lupus nephritis, other glomerulonephritis, Alport syndrome, and other conditions [39].

A few small, short-term studies suggest that the additive renal protection with combination therapy may be greater in patients with nondiabetic versus diabetic nephropathy. In a 12-week study directly comparing the effect of combining ARB and ACE inhibitor therapy in patients with IgA nephropathy versus diabetic nephropathy, the addition of candesartan to ramipril therapy had an additional antiproteinuric effect only in those with IgA nephropathy [40]. In a 16-week study conducted by the same group, addition of candesartan to ramipril therapy reduced urinary protein and transforming growth 

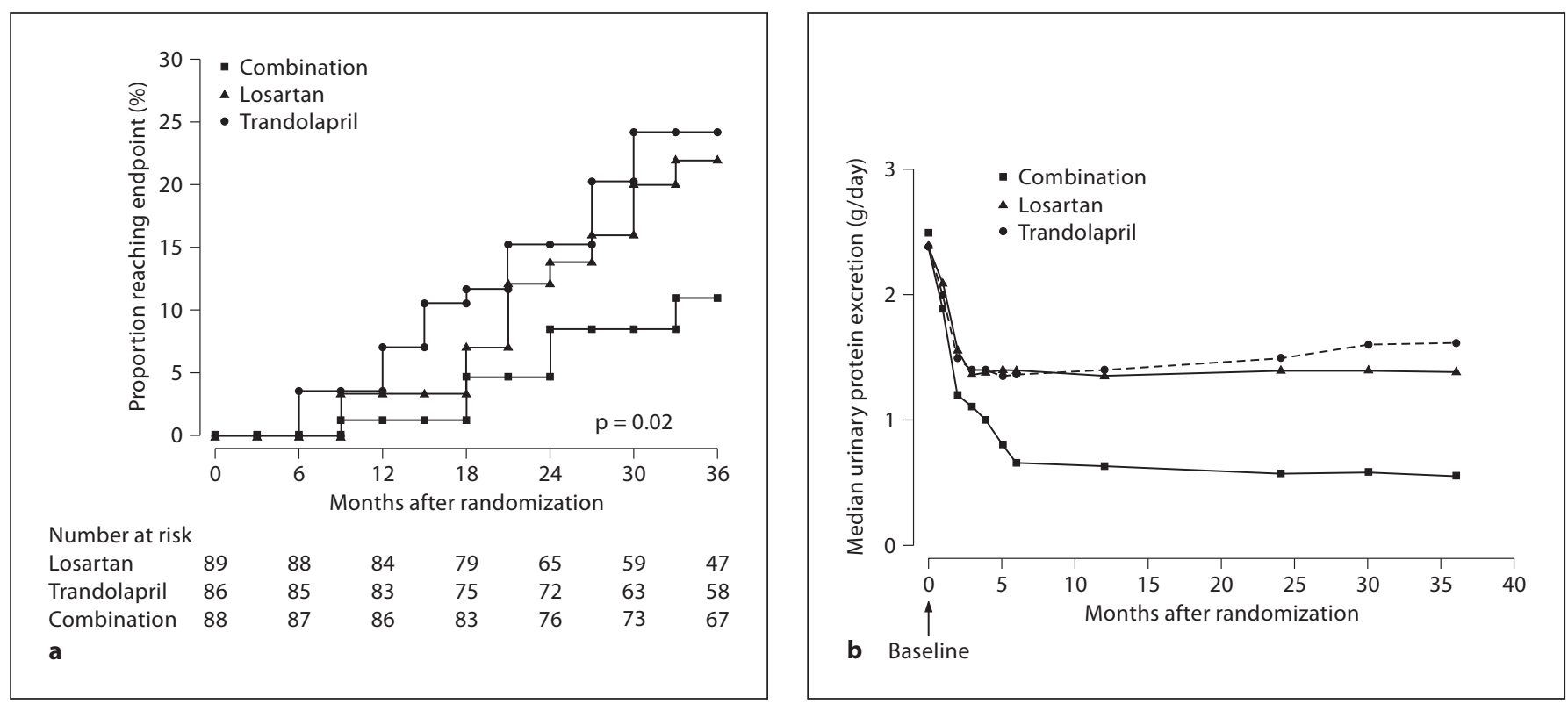

Fig. 2. Greater efficacy of combination treatment with a losartan- plus trandolapril-based regimen versus either a trandolapril- or losartan-based regimen in slowing progression of kidney disease (doubling of serum creatinine levels and ESRD) (a) and in reducing proteinuria (b) in patients with nondiabetic nephropathies. For figure $2 \mathrm{a}$, endpoint is time to doubling of serum creatinine or ESRD. Doses for combination therapy were 12.5 $\mathrm{mg}$ /day losartan plus $0.5 \mathrm{mg} /$ day trandolapril. Doses for control groups were $25 \mathrm{mg} /$ day losartan and $1 \mathrm{mg} / \mathrm{day}$ trandolapril. Reproduced with permission from Nakao et al. [43].

factor- $\beta_{1}$ levels in subjects with IgA but not those with diabetic nephropathy [41]. In a meta-analysis including short-term trials, addition of an ARB to ACE inhibitor therapy in subjects with nondiabetic renal disease resulted in a significant decrease in $24 \mathrm{~h}$ urine protein excretion compared with ACE inhibitor-based therapy (weighted mean difference, $440 \mathrm{mg} / 24 \mathrm{~h}$; $95 \%$ confidence interval (CI), 289-591 mg/24 h) [42]. In a subgroup analysis, there was a greater antiproteinuric effect in those with nondiabetic nephropathy compared with diabetic nephropathy (582 mg/24 h [95\% CI, 371-793 mg/24 h] vs. $210 \mathrm{mg} / 24 \mathrm{~h}$ [95\% CI, 84-336 mg/24 h]). Neither hyperkalemia nor acute decrease in estimated GFR was a major complication of combination therapy.

The long-term renoprotective efficacy and tolerability of combination therapy with an ACE inhibitor and an $\mathrm{ARB}$ in patients with nondiabetic nephropathy has been demonstrated in the COOPERATE study [43]. This double-blind study included 131 patients with IgA nephropathy, 36 with focal segmental sclerosis, 28 with membranous nephropathy, and 21 with membranoproliferative glomerulonephritis. Patients with nondiabetic proteinuric kidney disease were randomized to treatment with trandolapril plus losartan, or losartan or trandolapril alone on the background of conventional antihypertensives and were followed up for 3 years. Those assigned to combination therapy had a $60 \%$ lower rate of doubling of serum creatinine concentration or ESRD compared with the losartan or trandolapril groups (fig. 2a). ESRD occurred in $1 \%$ of subjects who received combination therapy versus $3 \%$ of those who received losartan and $8 \%$ of those who received trandolapril. In a secondary endpoint, combination treatment also resulted in a significantly greater rate of urinary protein excretion compared with either losartan- or trandolapril-based regimens; the maximum median change in daily urinary protein excretion for subjects who received combination treatment was $-75.6 \%$ (interquartile range -59.3 to $-87.9 \%$ ) versus $-42.1 \%$ (interquartile range -6.9 to $50.4 \%$ ) for subjects who received losartan and $-44.3 \%$ (interquartile range -5.6 to $-54.5 \%$ ) for those who received trandolapril-based regimen (fig. 2b) [43]. By design, treatment with a trandolapril- plus losartan-based regimen or losartan- or trandolapril-based regimen resulted in similar decreases in mean systolic and diastolic blood pressure $(\mathrm{p}=0.109)$. The possibility that the results 
of this study could be attributed to better blood pressure control in those treated with the combination drug therapy cannot be excluded because of difficulties in interpretation of the ambulatory substudy [44]. Improved blood pressure control particularly in the evening hours could in explain, in part or in full, the differences observed in the primary endpoint as well as the change in albuminuria. The frequency of adverse effects did not differ between the three treatment groups. Based on these findings, the National Kidney Foundation suggests that ACE inhibitors and ARBs may be used in combination to reduce proteinuria in hypertensive patients with diabetic or nondiabetic kidney disease, including patients in whom blood pressure is controlled using a single agent [3]. However, because of the limited studies of combinations of ACE inhibitors and ARBs in patients with CKD, the National Kidney Foundation recommends further and larger-scale studies of combination treatment [3].

\section{Combination Therapy with an ACE Inhibitor or ARB and a Mineralocorticoid Antagonist}

\section{Cardiovascular Outcomes}

Two large-scale clinical trials have examined the effect of adding a mineralocorticoid antagonist to an ACE inhibitor in patients with chronic heart disease. The Randomized ALdactone Evaluation Study (RALES) trial included 1,663 adults with severe systolic heart failure treated with an ACE inhibitor, digoxin and a diuretic and randomized them to receive either placebo or spironolactone $25 \mathrm{mg}$ once daily for up to 3 years [45]. The primary outcome variable was all-cause mortality. The trial was discontinued early because of an interim analysis demonstrating efficacy of spironolactone. The relative risk of death was 0.7 for those assigned to spironolactone as compared to those assigned to placebo. There was no significant difference in discontinuation for emergent hyperkalemia between the treatment arms although the incidence of hyperkalemia was higher in those assigned to spironolactone. The Eplerenone Post-AMI Heart Failure Efficacy and Survival Study (EPHESUS) randomized 2,200 patients who had a recent myocardial infarction to either placebo or eplerenone 25-50 mg once daily [46]. The primary outcome variable was all-cause mortality. In this study eplerenone was associated with a $20 \%$ relative risk reduction in all-cause mortality. Based on these trials the American Heart Association added the use of mineralocorticoid antagonists to their clinical practice guide- lines for management of heart failure in those with severe heart failure and those with heart failure post-myocardial infarction.

\section{Renal Outcomes}

There are no long-term, large-scale outcomes trials examining the impact of adding a MRA to an ACE inhibitor or an ARB. However, several small-scale, short-term studies have examined the effect of adding either spironolactone or eplerenone to an ACE inhibitor-based regimen in albuminuric type 1 and type 2 diabetics. These studies have consistently demonstrated further reduction in albuminuria in the ranges of $30-50 \%$ [47-51]. In the largest study to date, Epstein et al. [52] conducted a 12week, randomized, double-blind, placebo-controlled trial involving 268 hypertensive type 2 diabetics with a urine albumin/creatinine ratio $>50 \mathrm{mg} / \mathrm{g}$ while on treatment with enalapril $20 \mathrm{mg}$ once daily. Participants received placebo or 50 or $100 \mathrm{mg}$ of eplerenone. In contrast to a 7\% reduction in albuminuria observed with placebo administration, there were, on average, reductions of 41.0 and $48 \%$ on those receiving eplerenone 50 and $100 \mathrm{mg}$ once daily, respectively. Blood pressure was reduced to a slightly greater extent in those treated with either dose of eplerenone as compared to placebo. The incidence of mild and severe hyperkalemia was similar among the treatment groups, although it was slightly higher in those with an estimated GFR of $>85 \mathrm{ml} / \mathrm{min} / 1.73 \mathrm{~m}^{2}$ treated with 100 $\mathrm{mg}$ eplerenone once daily. As with the ACE inhibitor + ARB combination described above, the reported incidence of hyperkalemia necessitating drug discontinuation was low. However, the incidence of significant hyperkalemia is higher when these agents are added to an ACE inhibitor or ARB. Therefore, this combination should be used with caution particularly in diabetics with CKD.

\section{Combination Therapy with an ACE Inhibitor or ARB and a Renin Inhibitor}

Direct renin inhibitors is a new class of drugs that block the catalytic site of renin, thereby reducing formation of angiotensin I from angiotensinogen and hence the downstream effector angiotensin II (fig. 1) [7]. Preclinical data suggest that aliskerin, a direct renin inhibitor, provides similar renal protection as compared with an ARB in a rat model of hypertensive nephropathy [53]. The Aliskerin in the Evaluation of Proteinuria in Diabetes (AVOID) study was a multicenter, multinational randomized double-blind placebo-controlled trial that en- 
rolled 599 patients with type 2 diabetes and albuminuria. In a preliminary report, the addition of aliskerin $300 \mathrm{mg}$ once daily to losartan $100 \mathrm{mg}$ for 6 months was associated with a $20 \%$ reduction in albuminuria. There was no correlation between blood pressure and albuminuria reduction in this study [54]. A large-scale, randomized, double-blind, placebo-controlled trial based on this preliminary study is underway. The primary outcome variable in this study is the combination of doubling serum creatinine, ESRD, or death [55].

\section{Future Directions for Research}

More and larger long-term studies are needed to further examine renal outcomes with combination ACE inhibitor plus ARB treatment of CKD, including ESRD, and to further examine the efficacy of combination treatment in different subtypes of renal disease. The National Institute of Diabetes and Digestive and Kidney Diseases, for example, is sponsoring a 2 -year, phase 3 trial, expected to include 40 subjects, of the efficacy of combination therapy in treating primary hyperoxaluria [56]. Another trial, which is ongoing and expected to include 30 subjects, sponsored by the Ottawa Health Research Institute, will examine whether the addition of irbesartan to recommended doses of trandolapril is more effective than high doses of trandolapril alone in decreasing proteinuria in patients with diabetic nephropathy [57]. Because some patients treated with combination ACE inhibitor plus ARB treatment still have renal disease, future studies are also needed to examine the efficacy of blocking the RAAS in addition to non-RAAS targets. A trial is under way, expected to include 600 subjects, to examine the effectiveness of treating diabetic nephropathy with ACE inhibitors, ARBs, HMG-CoA reductase inhibitors, and vitamins; results are expected in 2011 [58].

The ONgoing Telmisartan Alone and in combination with Ramipril Global Endpoint Trial (ONTARGET) is a large, randomized controlled study, including 25,620 subjects at high risk for cardiovascular disease, expected to provide valuable results regarding the long-term renal outcomes with combination ramipril plus telmisartan [59]. Subjects include patients 55 years of age or older with a history of coronary artery disease, stroke, or transient ischemic attack within 1 week to less than 1 year, peripheral vascular disease, or diabetes with end-organ damage. A primary objective of ONTARGET is to compare the efficacy of telmisartan plus ramipril with ramipril alone in the composite outcome of cardiovascular death, nonfatal myocardial infarction, nonfatal stroke, or hospitalization for congestive heart failure. One secondary outcome is nephropathy: doubling of serum creatinine level and ESRD. Although the clinical implications are not known, the telmisartan, ARB used in ONTARGET, has several pharmacokinetic features that differentiate it from other ARBs; it insurmountably inhibits $\mathrm{AT}_{1}$ receptors [60, 61], it has a long half-life of about $24 \mathrm{~h}[62]$, and it is directly active, undergoing minimal transformation [63]. This study should provide additional important information on combination therapy in kidney disease. Results of ONTARGET are expected to be available in 2008 [64].

\section{Conclusions}

The RAAS plays a key role in the progression of chronic renal disease, and growing evidence suggests that combination treatment with an ACE inhibitor and an ARB may be beneficial. For those with CKD who tolerate combination therapy, this approach is a potentially favorable treatment option. The results of ongoing long-term studies utilizing the drugs ramipril and telmisartan, singly and in combination, should further elucidate the relative risks and benefits regarding renal outcomes with such combination therapies in patients with CKD.

\section{Acknowledgements}

Editorial assistance for the development of the manuscript was provided by Johanna B. Grossman, PhD, Boehringer Ingelheim Pharmaceuticals, Inc. This work was supported by Boehringer Ingelheim Pharmaceuticals, Inc.

References Kidney Foundation: K/DOQI clindisease: evaluation, classification, and stratification. Am J Kidney Dis 2002;39:S1S266.

2 US Renal Data System: USRDS 2005 Annual Data Report: Atlas of End-Stage Renal Disease in the United States. Bethesda, National Institutes of Health, National Institute of Diabetes and Digestive and Kidney Diseases, 2005. Available at: http://www.usrds.org/ adr.htm.

3 Kidney Disease Outcomes Quality Initiative (K/QODI): K/DOQI clinical practice guidelines on hypertension and antihypertensive agents in chronic kidney disease. Am J Kidney Dis 2004;43:S1-S290. 
4 Meguid El Nahas A, Bello AK: Chronic kidney disease: the global challenge. Lancet 2005;365:331-340.

5 Hsu C, Vittinghoff E, Lin F, Shilpak MG: Incidence of end-stage renal disease is increasing faster than the prevalence of chronic renal insufficiency. Ann Intern Med 2004;141: 95-101.

6 Xue JL, Ma JZ, Louis TA, Collins AJ: Forecast of the number of patients with end-stage renal disease in the United States to the year 2010. J Am Soc Nephrol 2001;12:2753-2758.

7 Brewster UC, Setaro JF, Perazella MA: The renin-angiotensin-aldosterone system: cardiorenal effects and implications for renal and cardiovascular disease states. Am J Med Sci 2003;326:15-24.

$>8$ American Diabetes Association: Standards of medical care in diabetes, 2005. Diabetes Care 2005;28:S4-S36.

$\checkmark 9$ Chobanian AV, Bakris GL, Black HR, Cushman WC, Green LA, Izzo JL Jr, Jones DW, Materson BJ, Oparil S, Wright JT Jr, Roccella EJ; Joint National Committee on Prevention, Detection, Evaluation, and Treatment of High Blood Pressure. National Heart, Lung, and Blood Institute; National High Blood Pressure Education Program Coordinating Committee: The Seventh Report of the Joint National Committee on Prevention, Detection, Evaluation, and Treatment of High Blood Pressure. Hypertension 2003;42: 1206-1252.

-10 Prasad P, Tiwari AK, Kumar KM, Ammini AC, Gupta A, Gupta R, Sharma AK, Rao AR, Nagendra R, Chandra TS, Tiwari SC, Rastogi P, Gupta BL, Thelma BK: Chronic renal insufficiency among Asian Indians with type 2 diabetes. I. Role of RAAS gene polymorphisms. BMC Med Genet 2006;7:42.

- 11 Lovati E, Richard A, Frey BM, Frey FJ, Ferrari P: Genetic polymorphisms of the reninangiotensin-aldosterone system. Kidney Int 2001;60:46-54.

- 12 Hsu CC, Bray MS, Kao WH, Pankow JS, Boerwinkle E, Coresh J: Genetic variation of the renin-angiotensin system and chronic kidney disease progression in black individuals in the atherosclerosis risk in communities study. J Am Soc Nephrol 2006;17:504512.

-13 Casas JP, Chua W, Loukogeorgakis S, Vallance P, Smeeth L, Hingorani AD, MacAllister RJ: Effect of inhibitors of the renin-angiotensin system and other antihypertensive drugs on renal outcomes: systematic review and meta-analysis. Lancet 2005;366:20262033.

- 14 Jafar TH, Schmid CH, Landa M, Giatras I, Toto R, Remuzzi G, Maschio G, Brenner BM, Kamper A, Zucchelli P, Becker G, Himmelmann A, Bannister K, Landais P, Shahinfar S, de Jong PE, de Zeeuw D, Lau J, Levey AS: Angiotensin-converting enzyme inhibitors and progression of nondiabetic renal disease. A meta-analysis of patient-level data. Ann Intern Med 2001;135:73-87.
15 Lewis EJ, Hunsicker LG, Bain RP, Rohde RD. The effect of angiotensin-converting-enzyme inhibition on diabetic nephropathy. N Engl J Med 1993;329:1456-1462.

16 Lewis EJ, Hunsicker LG, Clarke WR, Berl T, Pohl MA, Lewis JB, Ritz E, Atkins RC, Rohde R, Raz I; Collaborative Study Group: Renoprotective effect of the angiotensin-receptor antagonist irbesartan in patients with nephropathy due to type 2 diabetes. $\mathrm{N}$ Engl J Med 2001;345:851-860.

17 Brenner BM, Cooper ME, De Zeeuw D, Ke ane WF, Mitch WE, Parving $\mathrm{HH}$, Remuzzi G, Snapinn SM, Zhang Z, Shahinfar S; RENAAL Study Investigators: Effects of losartan on renal and cardiovascular outcomes in patients with type 2 diabetes and nephropathy. N Engl J Med 2001;345:861-869.

18 The GISEN Group (Gruppo Italiano di Studi Epidemiologici in Nefrologia): Randomised placebo-controlled trial of effect of ramipril on decline in glomerular filtration rate and risk of terminal renal failure in proteinuric, non-diabetic nephropathy. Lancet 1997;349: 1857-1863.

19 Maschio G, Alberti D, Janin G, Locatelli F, Mann JF, Motolese M, Ponticelli C, Ritz E, Zucchelli P: Effect of the angiotensin-converting enzyme inhibitor benazepril on the progression of chronic renal insufficiency. N Engl J Med 1996;334:939-945.

20 Hou FF, Zhang X, Zhang GH, Xie D, Chen PY, Zhang WR, Jiang JP, Liang M, Wang GB, Liu ZR, Geng RW: Efficacy and safety of benazepril for advanced chronic renal insufficiency. N Engl J Med 2006;354:131-140.

21 Van den Meiracker AH, Man in 't Veld AJ, Admiraal PJ, Ritsema van Eck HJ, Boomsma F, Derkx FH, Schalekamp MA: Partial escape of angiotensin converting enzyme (ACE) inhibition during prolonged ACE inhibitor treatment: does it exist and does it affect the antihypertensive response? J Hypertens 1992;10:803-812.

22 Burnier M, Brunner HR: Angiotensin II receptor antagonists. Lancet 2000;355:637645.

23 Unger T: Significance of angiotensin type 1 receptor blockade: why are angiotensin II receptor blockers different? Am J Cardiol 1999; 84:9S-15S.

24 Mogensen CE, Neldam S, Tikkanen I, Oren S, Viskoper R, Watts RW, Cooper ME: Randomized controlled trial of dual blockade of renin-angiotensin system in patients with hypertension, microalbuminuria, and noninsulin dependence diabetes: the candesartan and lisinopril microalbuminuria (CALM) study. BMJ 2000;321:1440-1444.

25 Jacobsen P, Andersen S, Jensen BR, Parving $\mathrm{HH}$ : Additive effect of ACE inhibition and angiotensin II receptor blockade in type II diabetic patients with diabetic nephropathy. J Am Soc Nephrol 2003;14:992-999.
26 Jacobsen P, Andersen S, Rossing K, Hansen BV, Parving HH: Dual blockade of the reninangiotensin system in type 1 patients with diabetic nephropathy. Nephrol Dial Transplant 2002;17:1019-1024.

27 Rossing K, Christensen PK, Jensen BR, Parving $\mathrm{HH}$ : Dual blockade of the renin-angiotensin system in diabetic nephropathy: a randomized double-blind crossover study. Diabetes Care 2002;25:95-100.

28 Rossing K, Jacobsen P, Pietraszek L, Parving $\mathrm{HH}$ : Renoprotective effects of adding angiotensin II receptor blockers to maximal recommended doses of ACE inhibitor in diabetic nephropathy: a randomized double-blind crossover trial. Diabetes Care 2003;26:22682274 .

-29 Jacobsen P, Andersen S, Rossing K, Jernsen $\mathrm{BR}$, Parving HH: Dual blockade of the reninangiotensin system versus maximal recommended dose of ACE inhibition in diabetic nephropathy. Kidney Int 2003;63:18741880.

30 Matos JP, de Lourdes Rodriguez M, Ismerim VL, Boasquevisque EM, Genelhu V, Franschetti EA: Effects of dual blockade of the renin angiotensin system in hypertensive type 2 diabetic patients with nephropathy. Clin Nephrol 2005;64:180-189.

31 Song JH, Cha SH, Lee HJ, Lee SW, Park GH, Lee SW, Kim MJ: Effect of low-dose dual blockade of renin-angiotensin system on urinary TGF- $\beta_{2}$ diabetic patients with advanced kidney disease. Nephrol Dial Transplant 2006;21:683-689.

32 Ferrari P, Marti HP, Pfister M, Frey FJ: Additive antiproteinuric effect of combined ACE inhibition and angiotensin II receptor blockade. J Hypertens 2002;20:125-130.

33 Russo D, Pisani A, Balletta MM, De Nicola L, Savino FA, Andreucci M, Minutolo R: Additive antiproteinuric effect of converting enzyme inhibitory and losartan in normotensive patients with IgA nephropathy. Am J Kidney Dis 1999;33:851-856.

34 Russo D, Minutolo R, Pisani A, Esposito R, Signoriello G, Andreucci M, Balletta MM: Coadministration of losartan and enalapril exerts additive antiproteinuric effect in IgA nephropathy. Am J Kidney Dis 2001;38:1825.

35 Berger ED, Bader ED, Ebert C, Risler T, Erley CM: Reduction of proteinuria; combined effects of receptor blockade and low dose angiotensin-converting enzyme inhibition. J Hypertens 2002;20:739-743.

36 Tylicki L, Rutkowski P, Renke M, Rutkowski B: Renoprotective effect of small doses of losartan and enalapril in patients with primary glomerulonephritis. Am J Nephrol 2002;22:356-362.

37 Rutkowski P, Tylicki L, Renke M, Korejwo G, Zdrojewski Z, Rutkowski B: Low-dose dual blockade of the renin-angiotensin system in patients with primary glomerulonephritis. Am J Kidney Dis 2004;43:260-268. 
-38 Agarwal R: Add-on angiotensin receptor blockade with maximized ACE inhibition. Kidney Int 2001;59:2282-2289.

39 Kincaid-Smith P, Fairley K, Packam D: Randomized controlled crossover study of the effect on proteinuria and blood pressure of adding an angiotensin II receptor antagonist to an angiotensin-converting enzyme inhibitor in normotensive patients with chronic renal disease and proteinuria. Nephrol Dial Transpl 2002;17:597-601.

40 Kim MJ, Song JH, Suh JH, Lee SW, Kim GA: Additive antiproteinuric effect of combination therapy with ACE inhibitor and angiotensin II receptor antagonist: differential short-term response between IgA nephropathy and diabetic nephropathy. Yonsei Med J 2003;44:463-472.

-41 Song JH, Lee SW, Suh JH, Kim ES, Hong SB, Kim KA, Kim MJ: The effects of dual block ade of the renin-angiotensin system on urinary protein and transforming growth factor- $\beta$ excretion in two groups of patients with IgA and diabetic nephropathy. Clin Nephrol 2003;60:318-326.

-42 MacKinnon M, Shurraw S, Akbari A, Knoll GA, Jaffey J, Clark HD: Combination therapy with an angiotensin receptor blockers and an ACE inhibitor in proteinuria renal disease: a systematic review of the efficacy and safety data. Am J Kidney Dis 2006;48:8-20.

-43 Nakao N, Yoshimura A, Morita H, Takada M, Kayano T, Ideura T: Combination treatment of angiotensin-II receptor blocker and angiotensin-converting-enzyme inhibitor in non-diabetic renal disease (COOPERATE): a randomized controlled trial. Lancet 2003;361:117-124.

-44 Bidani A: Controversy about COOPERATE ABPM trial data. Am J Nephrol 2006;26: 629-632.

45 Pitt B, Zannad F, Remme WJ, Cody R, Castaigne A, Perez A, Palensky J, Wittes J: The effect of spironolactone on morbidity and mortality in patients with severe heart failure. Randomized Aldactone Evaluation Study Investigators. N Engl J Med 1999;341: 709-717.

-46 Pitt B, Reichek N, Willenbrock R, Zannad F, Phillips RA, Roniker B, Kleiman J, Krause S, Burns D, Williams GH: Effects of eplerenone, enalapril, and eplerenone/enalapril in patients with essential hypertension and left ventricular hypertrophy: the $4 \mathrm{E}$-left ventricular hypertrophy study. Circulation 2003; 108:1831-1838.
47 Rossing K, Schjoedt KJ, Smidt UM, Boomsma F, Parving $\mathrm{HH}$ : Beneficial effects of adding spironolactone to recommended antihypertensive treatment in diabetic nephropathy: a randomized, double-masked, crossover study. Diabetes Care 2005;28:21062112.

48 Schjoedt KJ, Rossing K, Juhl TR, Boomsma F, Tarnow L, Rossing P, Parving HH: Beneficial impact of spironolactone on nephrotic range albuminuria in diabetic nephropathy. Kidney Int 2006;70:536-542.

49 Epstein M, Williams GH, Weinberger M, Lewin A, Krause S, Mukherjee R, Patni R, Beckerman B: Selective aldosterone blockade with eplerenone reduces albuminuria in patients with type 2 diabetes. Clin J Am Soc Nephrol 2006;1:940-951.

50 Van den Meiracker AH, Baggen RG, Pauli S, Lindemans A, Vulto AG, Poldermans D, Boomsma F: Spironolactone in type 2 diabetic nephropathy: effects on proteinuria, blood pressure and renal function. J Hypertens 2006;24:2285-2292.

51 Chrysostomou A, Pedagogos E, MacGregor L, Becker GJ: Double-blind, placebo-controlled study on the effect of the aldosterone receptor antagonist spironolactone in patients who have persistent proteinuria and are on long-term angiotensin-converting enzyme inhibitor therapy, with or without an angiotensin II receptor blocker. Clin J Am Soc Nephrol 2006;1:256-262.

52 Epstein M, Williams GH, Weinberger M, Lewin A, Krause S, Mukherjee R, Patni R, Beckerman B: Selective aldosterone blockade with eplerenone reduces albuminuria in patients with type 2 diabetes. Clin J Am Soc Nephrol 2006;1:940-951.

53 Muller DN, Luft FC: Direct renin inhibition with aliskiren in hypertension and target organ damage. Clin J Am Soc Nephrol 2006;1: 221-228.

54 Parving HH, Lewis, JB, Lewis EJ, Hollenberg NK: Aliskerin in the Evaluation of Proteinuria in Diabetes (AVOID) (abstract). J Am Soc Nephrol 2007, online.

55 Parving $\mathrm{HH}$, Brenner BM, McMurray JJV, de Zeeuw D, Haffner SM, Solomon SD, Chaturvedi N, Ghadanfar M, Weissbach N, Xiang Z, Pfeffer MA: ALiskiren Trial In Type 2 Diabetes Using Cardio-Renal Disease Endpoints (ALTITUDE): Rationale and Study Design (abstract). J Am Soc Nephrol 2007, online.

56 National Institute of Diabetes and Digestive Kidney Diseases: Renal protective effect of ACEI and ARB in primary hyperoxaluria. Available at: http://www.clinicaltrials.gov/ ct/show/NCT00280215?order $=1$.
57 Ottawa Health Research Institute: Addition of angiotensin receptor blockade to ACE inhibition versus high dose ACE inhibition for reduction of proteinuria in patients with diabetic nephropathy. Available at: http://www.clinicaltrials.gov/ct/show/ NCT00212901 order $=5$.

58 Okayama University: Study for the effectiveness of intensive therapy for diabetic nephropathy I unblended, randomized intergroup comparison study. Available at: http://www.clinicaltrials.gov/ct/show/ NCT00253786? order $=16$.

59 Teo K, Yusuf S, Sleight P, Anderson C, Mookadam F, Ramos B, Hilbrich L, Pogue J, Schumacher H; ONTARGET/TRANSCEND Investigators: Rationale, design, and baseline characteristics of two large, simple, randomized trials evaluating telmisartan, ramipril, and their combination in high-risk patients: the Ongoing Telmisartan Alone and in Combination with Ramipril Global Endpoint Trial/Telmisartan Randomized Assessment Study in ACE Intolerant Subjects with Cardiovascular Disease (ONTARGET/TRANSCEND) trials. Am Heart J 2004; 148:52-61.

60 Wienen W, Hauel N, Van Meel JC, Narr B, Ries U, Entzeroth M: Pharmacological characterization of the novel nonpeptide angiotensin II receptor antagonist, BIBR 277. Br J Pharmacol 1993;110:245-252.

61 Maillard MP, Perregaux C, Centeno C, Stangier J, Wienen W, Brunner HR, Burnier $\mathrm{M}$ : In vitro and in vivo characterization of the activity of telmisartan: an insurmountable angiotensin II receptor antagonist. J Pharmacol Exp Ther 2002;302:1089-1095.

-62 Stangier J, Su CA, Roth W: Pharmacokinetics of orally and intravenously administered telmisartan in healthy young and elderly volunteers and in hypertensive patients. J Int Med Res 2000;28:149-167.

63 Stangier J, Schmid J, Turck D, Switek H, Verhagen A, Peeters PA, van Marle SP, Tamminga WJ, Sollie FA, Jonkman JH: Absorption, metabolism, and excretion of intravenously and orally administered $\left[{ }^{14} \mathrm{C}\right]$ telmisartan in healthy volunteers. J Clin Pharmacol 2000; 40:1312-1322.

64 ONTARGET: ONgoing Telmisartan Alone and in Combination with Ramipril Global Endpoint Tria Parallel Trial. TRANSCEND Telmisartam Randomized AssessmeNt Study in aCE iNtolerant Subjects with Cardiovascular Disease Trial. Available at: http://www.clinicaltrials.gov/ct/show/ NCT00153101?order $=1$ 